\title{
ODPOWIEDZIALNOŚĆ ZA WYCHOWANIE DZIECI W WYBRANEJ LITERATURZE WCZESNOCHRZEŚCIJAŃSKIEJ
}

Zagadnienie wychowania dzieci w świecie grecko-rzymskim było już przedmiotem badań wielu uczonych ${ }^{1}$. Niemniej, w niniejszym opracowaniu, postanowiono poddać analizie kwestię odpowiedzialności za wychowanie dzieci ${ }^{2}$ poruszaną $\mathrm{w}$ greckojęzycznej literaturze wczesnochrześcijańskiej powstałej na terenie Syrii w III-IV wieku. W artykule podjęto także próbę ukazania jak autorzy wczesnochrześcijańscy uzasadniają teologicznie tę odpowiedzialność, jaką treścią wypełniają proces wychowania dzieci oraz jakie wskazują metody i cel wychowania.

W greckojęzycznym środowisku syryjskim III-IV w. powstało niewiele pism, których głównym tematem jest wychowanie dzieci. Najbardziej obszerne rozważania na ten temat są przedstawione w traktacie Jana Chryzostoma De inani gloria et de educandis liberis ${ }^{3}$. Chryzostom udziela rad mających ułatwić wychowanie dzieci, podkreślając poważną odpowiedzialność rodzi-

${ }^{*}$ Ks. dr hab. Piotr Szczur, prof. KUL - kierownik Katedry Historii Kościoła w Starożytności Chrześcijańskiej w Instytucie Historii Kościoła i Patrologii na Wydziale Teologii Katolickiego Uniwersytetu Lubelskiego Jana Pawła II; e-mail: p.szczczur@kul.pl.

${ }^{1}$ Zob. np. bibliografie: Matżeństwo i rodzina w starożytności chrześcijańskiej [materiały bibliograficzne] (S. Longosz), VoxP 5 (1985) t. 8-9, 449-507, spec. dział II/2 - Dziecko (s. 480-482) i IV - Wychowanie dzieci i młodzieży (s. 488-496); Matżeństwo, rodzina i wychowanie w nauczaniu Jana Chryzostoma. Materiały bibliograficzne (S. Longosz), VoxP 29 (2009) t. 53-54, 805-812, spec. dział C - Wychowanie (s. 809-812).

${ }^{2}$ Pomimo tego, iż podstawowe terminy ( $\left.\pi \alpha \imath \delta \varepsilon v ́ \omega / \pi \alpha \imath \delta \varepsilon i ́ \alpha\right)$, których źródła używają na określenie działalności, którą będziemy omawiać, nie czynią rozróżnienia pomiędzy określeniami „wychowanie” i ,edukacja”, to jednak należy zauważyć, że nie są to wyrażenia synonimiczne. „Wychowanie" określa całość działań rodziców (i innych osób przynależnych do starożytnej rodziny lub familii) wobec dzieci w celu nauczenia ich szczegółowych zachowań, podczas gdy „edukacja” określa jedynie jeden z wymiarów tej działalności. Rozumiane w tym kluczu „wychowanie” jest zatem pojęciem o wiele szerszym, obejmującym również „edukację” (co znajduje odzwierciedlenie w prezentowanym i analizowanym materiale źródłowym). Czasownik $\pi \alpha \imath \delta \varepsilon v ́ \omega$ przyjmuje następujące znaczenia: „I. wychowywać dziecko, wykarmić; II. 1. uczyć, kształcić, wychowywać; o koniach, tresować; 2. poprawiać; 3. karcić, karać" (Abramowiczówna III 363); por. Liddell - Scott, s. 1286-1287; Lampe, s. 995-996.

${ }^{3}$ Ed. A.M. Malingrey: Jean Chrysostome, Sur la vaine gloire et l'éducation des enfants, SCh 188, Paris 1972, thum. W. Kania: O wychowaniu dzieci, w: Św. Jan Chryzostom, Wybór pism, PSP 
ców, aby wychowali dzieci w wierze chrześcijańskiej i przyswoili im chrześcijański sposób życia. Traktat ten, wraz z fragmentami kilku innych pism tego samego autora, jest fundamentalny dla naszego tematu. Ponadto rozważanemu tematowi poświęcone są znaczne partie dwóch ważnych pism o charakterze prawniczym: Didaskaliów ${ }^{4}$ oraz Konstytucji Apostolskich ${ }^{5}$. Pomimo, iż także w innych pismach można znaleźć bardziej lub mniej przypadkowe odniesienia do prezentowanego tematu, to jednak w niniejszych rozważaniach ograniczono się do analizy wspomnianych źródeł.

Aby treści przekazywane przez analizowane źródła chrześcijańskie, mówiące o wychowaniu, ukazać w kontekście kulturowym, należy rozpocząć od wskazania kilku ogólnych, lecz fundamentalnych aspektów wychowania w świecie grecko-rzymskim. Pozwoli to na krótką refleksję związaną z odpowiedzią na pytanie: czy ideały zaproponowane przez autorów chrześcijańskich znacznie różnią się od wzorców propagowanych przez kulturę klasyczną?

\section{WYBRANE ASPEKTY WYCHOWANIA DZIECI W KULTURZE GRECKO-RZYMSKIEJ}

W świecie grecko-rzymskim powszechne było uznawanie dzieci za istoty nie mające rozsądku. Przekonanie to znajduje szerokie odzwierciedlenie w źródłach literackich już od czasów Homera, aż po Cycerona ${ }^{6}$. Okres dojrzewania płciowego był postrzegany jako decydująca faza w rozwoju dziecka, ponieważ przynosił on nie tylko rozwój związany ze zmianami fizyczny$\mathrm{mi}$, ale także fundamentalną zmianę w sferze intelektualnej. W tym okresie

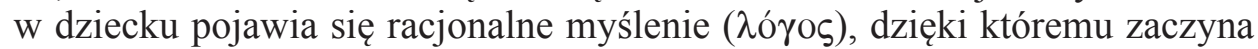
rozwijać w sobie zdolność rozróżniania między dobrem a złem oraz między dobrym a złym zachowaniem? ${ }^{7}$.

Założenie, że dziecko przed okresem dojrzewania nie rozwinęło swego potencjału racjonalnego myślenia, nie dowodzi, że wychowawca przed tym okresem nie powinien podejmować wysiłków w celu wpojenia dziecku obowiązujących wzorców dobrego zachowania oraz wychowywania go według jego zasad. Dlatego niektórzy autorzy podkreślali, że dzieci są „miękkie” i ,plastyczne", i łatwo ulegają wpływom innych osób. Przykładowo, Platon porównuje dziecko do „tabliczki woskowej” i podkreśla, że to, z czym dzieci spotkają się w czasie, gdy są małe, jest szczególnie ważne, ponieważ ich „ta-

13, Warszawa 1974, 157-185, przedruk w: Św. Jan Chryzostom, O matżeństwie, wychowaniu dzieci i ascezie, BOK 19, Kraków 2002, 73-105.

${ }^{4}$ Ed. A. Wööbus: The Didascalia Apostolorum in Syriac (Chapters I-X), CSCO 401, (Chapters XI-XXVI), CSCO 407, Louvain 1979.

${ }^{5}$ Constitutiones Apostolorum, ŹMT 42 [tekst grecko-polski, układ i oprac. A. Baron - H. Pietras, thum. S. Kalinkowski] = SCL 2, Kraków 2007, 1-293.

${ }^{6}$ Por. T. Wiedemann, Adults and Children in the Roman Empire, London 1989, $22-23$.

${ }^{7}$ Temat ten obecny jest w literaturze do IV wieku. Por. Wiedemann, Adults and Children, s. 24. 
bliczka” w tym czasie jest wciąż świeża i nowa ${ }^{8}$. Ta idea jest także odzwierciedlona u Kwintyliana, który mówi, że ktoś, kto uczy dzieci, odciska znak na nieukształtowanym umyśle ${ }^{9}$. Odnosząc się do Platona, Pseudo-Plutarch także stosuje obraz tabliczki woskowej, aby w ten sposób podkreślić, jak ważne jest zrozumienie, że właściwe kształtowanie charakteru dziecka zaczyna się już we wczesnym okresie. Faktycznie, zaczyna się od momentu urodzenia, poprzez wybór niań i służących ${ }^{10}$.

Obraz tabliczki woskowej zastosowany przez autorów starożytnych do opisu dzieci dowodzi, że są one uważane za niedoskonały, „surowy materiał”, który przez wychowanie i kształcenie musi być przekształcony w „,coś” szlachetnego. Idea dziecka jako „surowego materiału” obecna też jest u Kwintyliana, który jeszcze bardziej ją akcentuje i uwypukla poprzez zastosowanie obrazu nauczyciela jako artysty, który kształtuje (formanda) ucznia w piękny posąg ${ }^{11}$. Zauważa on, że nie ma dziecka zbyt małego, aby nie mogło być przedmiotem właściwego kształtowania moralnego ${ }^{12}$.

Z powyższej prezentacji jasno wynika, że wspomniani wybitni autorzy uważali formację moralną za istotny element wychowania dzieci, zarówno w domach jak i w szkołach. Pseudo-Plutarch podsumowując cel wychowania stwierdza, że powinien on zdążać do osiągnięcia cnoty i szczęścia ${ }^{13}$. Szczęście odnosi się tutaj do dobrego życia, które jest wynikiem życia cnotliwego. Zatem wiedza i umiejętności, które uczniowie zdobywają w szkole, ostatecznie mają na celu przygotowanie do życia zgodnego ze standardami cnót filozofii moralnej, co także dowodzone jest przez autorów, takich jak Seneka ${ }^{14}$ czy Filon Aleksandryjski ${ }^{15}$.

Wypowiedzi innych autorów odzwierciedlają świadomość wagi roli rodziców dla rozwoju charakteru dziecka i związku istniejącego między wychowaniem, które dziecko otrzymuje, i jego zachowaniem, kiedy jest ono starsze ${ }^{16}$.

${ }^{8}$ Por. Plato, Leges VII 789E; tenże, Respublica II 377A-B. Zob. Aristoteles, Politica VII 1336a10; M. Golden, Children and Childhood in Classical Athens, Bltimore 1990, 8-9.

${ }^{9}$ Por. Quintilianus, Marcus Fabius, Institutio oratoria I 1, 36.

${ }^{10}$ Por. Pseudo-Plutarchus, Moralia 3 E-F.

${ }^{11}$ Por. Quintilianus, Marcus Fabius, Institutio oratoria II 19, 3.

${ }^{12}$ Por. tamże I 3, 12. W innym fragmencie określa uczniów jako tych, którzy „pozwalają się tylko kształtować przez drugich (formandos se tantummodo praestant)", przekł. polski M. Brożek, w: M. Fabiusz Kwintylian, Kształcenie mówcy. Księgi I, II, X, Wrocław 2005, 136.

${ }^{13}$ Por. Pseudo-Plutarchus, De liberis educandis 8.

${ }^{14}$ Por. Seneca, Epistula 88.

${ }^{15}$ Por. Philo Judaeus, De agricultura 7-25.

${ }^{16}$ Por. S. Dixon, The Roman Family, Baltimore 1992, 118: „It is not difficult to assemble texts to show that ancient authors saw the parental role as vital to the development of a child's character. Statements commonly take the form of deploring modern trends that impose insufficient disciple on the young child or youth or of praising the parents of a famous man for instilling virtue in him from his earliest years". Suzanne Dixon odnosi się do następujących tekstów: Plautus, Mostellaria 118121; Aristoteles, De juventute et senectute 14; Tacitus Cornelius, Dialogus de Oratoribus 28-29; Horatius Flaccus, Quintus, Sermones I 6, 71-92; tenże, Carmina III 6, 37-41. 
Jednak należy też zauważyć, że niektórzy autorzy, np. Cycero, podkreślają, iż nie można obarczać rodziców odpowiedzialnością za błędy popełniane przez ich synów ${ }^{17}$, przez co wyraźnie wskazują, że postępowanie dziecka nie jest podyktowane jedynie takim, czy innym wychowaniem. Natomiast starożytni biografowie wydają się przypuszczać, że charakter osoby nie jest rezultatem wychowania, lecz skutkiem właściwego rozwoju biologicznego ${ }^{18}$. Tak więc w przekazach przedchrześcijańskich autorów starożytnych dostrzega się świadomość, że rodzice mają obowiązek ,zasiewać” w swych dzieciach właściwe cnoty, jednak nie mogą być całkowicie odpowiedzialni za ich przyszłe postępowanie $^{19}$.

Osobą odpowiedzialną za edukację w starożytnej rodzinie był paterfamilias - głowa rodziny ${ }^{20}$, który praktycznie posiadał prawie niczym nie ograniczoną władzę nie tylko nad dziećmi, lecz także nad wszystkimi członkami gospodarstwa domowego. Władzę tę paterfamilias mógł prawie dowolnie wykorzystywać, bez obawy ponoszenia konsekwencji jurydycznych ${ }^{21}$, zaś wszyscy domownicy byli zobowiązani do okazywania mu posłuszeństwa i szacunku ${ }^{22}$. Chociaż całkowita odpowiedzialność za wychowanie dzieci spoczywała na ojcu, to jednak matka była bardziej zaangażowana $\mathrm{w}$ ich formację ${ }^{23}$. W tym miejscu należy też zauważyć, że w rodzinach dobrze sytuowanych, zatrudniano nianie, nauczycieli i innych służących, których zadaniem było wychowanie,

${ }^{17}$ Por. Cicero, Marcus Tullius, Epistulae ad Atticum X 4, 6.

${ }^{18}$ Por. Widemann, Adults and Children, s. 49-83; Dixon, The Roman Family, s. 118.

${ }^{19}$ Suzanne Dixon (The Roman Family, s. 98) porównuje współczesne i starożytne myślenie o szczególnej odpowiedzialności rodziców za rozwój dzieci i wnioskuje: „the idea that parents were entirely responsible for their children's adult character was not as consistently argued or as firmly entrenched as it is in the postpsychoanalytic West".

${ }^{20}$ Por. O. Jurewicz - L. Winniczuk, Starożytni Grecy i Rzymianie w życiu prywatnym i państwowym, Warszawa 1973, 11. Szerzej na temat pozycji i autorytetu ojca w gospodarstwie domowym (paterfamilias) zob. J.A. Crook, Patria Potestas, CQ 17(1967) 113-122; D. Daube, Roman Law: Linguistic, Social and Philosophical Aspects, Edinburg 1969; W.K. Lacey, Patria Potestas, w: The Family in Ancient Rome: New Perspectives, ed. B. Rawson, Ithaca (New York) 1987, 121-144; B. Rawson, Children in the Roman Family, w: The Family in Ancient Rome, s. 1-57 (spec. 15-31); B. Czyżewski, ,Pater familias” i jego zadania wedlug św. Jana Chryzostoma, VoxP 29 (2009) t. 53-54, 205-221.

${ }^{21}$ W III i IV w. po Chr., pojawia się tendencja do ograniczania absolutnej władzy paterfamilias nad innymi członkami rodziny. Jest to szczególnie widoczne w pojawiających się wówczas kwestiach dotyczących dziedziczenia i prawa do własności. Szerzej na ten temat zob. J.E. Grubbs, Law and Family in Late Antiquity: The Emperor Constantine's Marriage Legislation, Oxford 1955; A. Arjava, Women and Law in Late Antiquity, Oxford 1996; tenże, Paternal Power in Late Antiquity, JRS 88 (1998) 147-165; M. Kuefler, The Manly Eunuch: Masculinity, Gender Ambiguity, and Christian Ideology in Late Antiquity, Chicago 2001, 70-76.

${ }^{22}$ Por. Czyżewski, Pater familias i jego zadania, s. 205.

${ }^{23}$ Szerzej na temat roli matki zob. J. Jurkiewicz, , Mater familias” w nauczaniu św. Jana Chryzostoma, VoxP 29 (2009) t. 53-54, 223-231. 
kształcenie i nadzorowanie dzieci oraz troska o nie w sprawach codziennych ${ }^{24}$. Gdy autorzy, tacy jak Cycero, Kwintylian i Tacyt, mówią o relacjach między matkami i dziećmi, nie zakładają, ani też nie zalecają bliskich, emocjonalnych związków, gdyż takie związki powinny istnieć między dziećmi, a ich nianiami i innymi służącymi, a nie między dziećmi i ich matkami ${ }^{25}$.

Hierarchiczna struktura rodziny w starożytności klasycznej połączona z prawie niczym nieograniczoną władzą ojca, stwarzała niebezpieczeństwo niewłaściwego traktowaniem dzieci przez użycie wobec nich siły fizycznej. Należy jednak zaznaczyć, że obowiązujący wówczas ideał bonus paterfamilias - „dobry” ojciec rodziny, w przeciwieństwie do malus paterfamilias „zły” ojciec rodziny, wyraźnie wskazuje, że dzieci powinny być traktowane sprawiedliwie, z pełnym szacunkiem, a kary fizyczne powinny być stosowane wobec nich $\mathrm{z}$ umiarem $\mathrm{i}$ jedynie $\mathrm{w}$ uzasadnionych sytuacjach ${ }^{26}$. Trudno jest określić zasięg faktycznego wpływu tego ideału na sposób traktowania dzieci. Natomiast bez trudu można przytoczyć teksty, które zakładają lub odzwierciedlają fakt, że dzieci były bite oraz surowo karane przez swych rodziców ${ }^{27}$. Niemniej jednak fakt, że źródła na ogół wiążą karę cielesną z działalnością pedagogów i nauczycieli, a nie rodziców, może wskazywać, że między ideałem

${ }^{24}$ Por. K.R. Bradley, Wet-Nursing at Rome, w: The Family in Ancient Rome, s. 201-229; S. Dixon, The Roman Mother, London 1988, 120-128.

${ }^{25}$ Istniała tendencja, by za podstawowe zadanie matek uznać kierowanie do dzieci mów, w których przedstawiałyby im pewne wzory, aby w ten sposób pomagać innym wychowawcom i opiekunom zasiewać w dzieciach ziarna odpowiednich cnót, tak szybko, jak były one w stanie to zrozumieć (por. Tacitus, Dialogus de Oratoribus 28; Quintilianus, Institutio oratoria I 1, 5; Cicero, Marcus Tullius, Brutus 210-212; Dixon, The Roman Family, s. 109-111). Oczekiwano, aby w miarę wzrostu dziecka, matka odgrywała coraz bardziej bezpośrednią rolę w jego życiu. Suzanne Dixon zauważa, że w czasach współczesnych mamy tendencję, by najpierw widzieć dziecko w domu z matką, a później w szkole z nauczycielem. Natomiast Rzymianie uważali, że najpierw dzieckiem powinny zająć się niańki, a następnie nauczyciele i rodzice: „Where we tend to see that part of the life cycle as at home with Mother, then at school with Teacher; Romans saw it as spent with nurses, then with teachers and parents" (taż, The Roman Family, s. 129). Matki były szczególnie zaangażowane w wychowanie i edukację córek, które miały przygotować do przyszłych ról dobrych żon. Ideałem było posiadanie przez matkę pełnej kontroli nad córką, która nie powinna niczego ukrywać przed swoją matką, nawet po wyjściu za mąż. Na temat związku między matkami i nastoletnimi lub dorosłymi dziećmi zob. Dixon, The Roman Family, s. 168-209.

${ }^{26}$ Por. R. Aasgaard, „, My Beloved Brothers and Sisters”. A Study of the Meaning and Function of Christian Siblingship in Paul: in its Greco-Roman and Jewish Context, Oslo 1998, 59-61; G.S. Nathan, The Family in Late Antiquity: The Rise of Christianity and the Endurance of Tradition, London 2000, 27-28. Richard Saller (Corporal Punishment, Authority and Obedience in the Roman Household, w: Marriage, Divorce and Children in Ancient Rome, ed. B. Rawson, Oxford 1991, 144-165) wyjaśnia, że bicie i kopanie były uważane za właściwe metody karania niewolników; bicie wolnej osoby było uważane za atak na jej dignitas. Z tego względu Saller wnioskuje, że rodzice tylko sporadycznie bili swe dzieci, gdyż takie postępowanie uważane było za niewłaściwe, a ponadto powodowało rodzenie się w dzieciach niewłaściwych uczuć wobec tych, którzy je bili.

${ }^{27}$ Por. Dixon, The Roman Family, s. 118; Nathan, The Family in Late Antiquity, s. 32-33. 
bonus paterfamilias a rzeczywistością była pewna zgodność ${ }^{28}$. Natomiast w kontekście systemu nauczania, stosowanie kar cielesnych wobec dzieci było codzienną rzeczywistością, akceptowaną społecznie ${ }^{29}$.

\section{WYCHOWANIE DZIECI \\ W WYBRANYCH GRECKICH ŹRÓDŁACH CHRZEŚCIJAŃSKICH}

Wskazówki dotyczące wychowania dzieci zawarte w najwcześniejszych tekstach chrześcijańskich - Nowym Testamencie oraz w tekstach Ojców Apostolskich - nie są liczne, jednak fakt, że występują one w wypowiedziach o charakterze parenetycznym, jednoznacznie wskazuje na świadomość pierwszych chrześcijan, że rodzice byli zobowiązani do wychowania swych dzieci w religii chrześcijańskiej ${ }^{30}$. Główny akcent tych tekstów położony jest przede wszystkim na obowiązek rodziców, by wychowywali swe dzieci w „bojaźni Bożej”. Przykładowo, kompilator Didache daje rodzicom wskazania następującej treści:

„Nie trzymaj twojej ręki z dala od syna lub córki twojej, lecz już od dzieciństwa ucz ich bojaźni Bożej”’31.

Zalecenie to jest ogólnym wskazaniem, aby rodzice dali swym dzieciom chrześcijańskie wychowanie, które powinno koncentrować się na przyswajaniu chrześcijańskich cnót:

„Niech dzieci nasze uczestniczą w wychowaniu w Chrystusie. Niechaj się uczą, jak ogromną ma siłę wobec Boga pokora, ile może u Boga czysta mi-

${ }^{28}$ Por. Dixon, The Roman Family, s. 118. Geoffrey Nathan (The Family in Late Antiquity, s. 33) podkreśla, że bicie dzieci często było reakcją natychmiastową. Jednak jeśli syn zrobił coś niewłaściwego, to było czymś nieprawdopodobnym, by został ukarany, chyba, że źle zachował się przy ojcu: „The tendency to hit one's offspring was frequently reactive and immediate. Unless a son had done something outrageous, he was unlikely to be punished unless he misbehaved in front of his father". Natomiast niektórzy uczeni są zdania, że rodzice często stosowali kary cielesne (zob. L. De Mause, The Evolution of Childhood, w: The History of Childhood: The Evolution of Parent-Child Relationships as a Factor in History, ed. L. De Mause, London 1974, 39-41; Wiedemann, Adults and Children, s. 28-30 i 104-106).

${ }^{29}$ T. Wiedemann (Adults and Children, s. 28-29) odnosi się do wielu tekstów źródłowych i zauważa, że podobnie jak bat był symbolem wyższości pana nad niewolnikiem, tak rózga nauczyciela stała się symbolem władzy mistrza nad uczniami. Związek pomiędzy karami cielesnymi a nauczaniem nie zmieniał się przez cały okres starożytności. Z tego względu nie dziwi fakt, że w przekazach źródłowych znajdujemy informacje o uczniach, którzy w odwecie za doznane krzywdy, napadali na swych nauczycieli.

${ }^{30}$ Por. Ef 6, 1-4; Kol 3, 20-21; Tt 1, 6-9; 1 Tm 3, 4; Didache IV 9; Barnabae epistula XIX 5; Polycarpus, Epistula ad Philippenses IV 2; Clemens Romanus, Epistula I ad Corinthios XXI 6. 8.

${ }^{31}$ Didache IV 9, ed. W. Rordorf: La doctrine des douz apôtres (Didachè), SCh 248, Paris 1978, 162, tłum. A. Świderkówna, w: Pierwsi świadkowie. Pisma Ojców Apostolskich, BOK 10, Kraków 2010,35 . 
łość, jak piękna i wielka jest bojaźń Boża, zdolna zbawić każdego, kto żyje w niej święcie szczerym sercem" ${ }^{32}$.

Jednak ani Nowy Testament, ani Ojcowie Apostolscy nie omawiają treści i sposobów wychowania dzieci; jedynie przekazują ogólne napomnienia, aby kształtować je przez zachęcanie i nauczanie. Z tego względu poniżej zostaną zaprezentowane treści dotyczące tego zagadnienia, zaczerpnięte z Didaskaliów, Konstytucji Apostolskich i wybranych pism Jana Chryzostoma.

1. Didaskalia. Zbiór ten ${ }^{33}$ poświęca jeden niewielki rozdział (XXII) wychowaniu dzieci. Kontekst wskazuje, że kompilator ma na myśli dzieci, które dzisiaj określilibyśmy jako nastoletni chłopcy, i akcentuje obowiązek rodziców, aby wychowali ich zgodnie z ideałami chrześcijańskimi. Główny nacisk zawartych w Didaskaliach wypowiedzi na temat wychowania położony jest na stwierdzeniu, że rodzice są odpowiedzialni przed Bogiem za grzechy swych dzieci. Autor koncentruje się na grzechach związanych z ludzką seksualnością i podkreśla, że rodzice są winni, gdy Bóg potępi dusze ich dzieci z powodu takich grzechów: pomimo tego, że synowie grzeszą

„bez rodziców, to oni sami będą winni przed Bogiem złego osądu ich [tj. dzieci] dusz. Albo jeszcze, jeżeli przez wasze przyzwolenie pozostają oni bez dyscypliny i grzeszą, to znowu wy, ich rodzice, będziecie za nich winni przed Bogiem"34.

Jednak ważniejsze od kwestii związanych z dokładnym określeniem grzechów, jest jasne sformułowanie zasady, że rodzice są odpowiedzialni za wieczny los swych dzieci, i że będą wezwani przez Boga, aby wytłumaczyć się, jeśli ich zaniedbania w stosowaniu dyscypliny doprowadziły ich dzieci do grzechu. Wydaje się, że trudno byłoby mocniej podkreślić odpowiedzialność rodziców i ciążący na nich obowiązek wychowania dzieci zgodnie z ideałami chrześcijańskimi. Być może wskazania te powinny być rozpatrywane w kontekście żydowskiego pochodzenia autora, gdyż w kulturze żydowskiej niezmiernie ważny był obowiązek ciążący na rodzicach, aby uczyli swe dzieci praw Boskich i wpajali im konieczność realizowania różnych praktyk religijnych ${ }^{35}$.

${ }^{32}$ Clemens Romanus, Epistula I ad Corinthios, XXI 8, ed. A. Jaubert: Clément de Rome, Épître aux Corinthiens, SCh 167, Paris 1971, s. 138, tłum. A. Świderkówna, BOK 10, 61.

${ }^{33}$ Didaskalia są zbiorem ustaw kościelnych, powstałym w pierwszej połowie III w., skierowanym do chrześcijan nawróconych z pogaństwa w Syrii północnej. Anonimowym autorem dzieła jest biskup, prawdopodobnie nawrócony z judaizmu, który przy pisaniu dzieła w znacznym stopniu opierał się na apokryfach Nowego Testamentu. Podstawowym celem Didaskaliów jest udzielenie wiernym wskazówek moralnych oraz przedstawienie różnych przepisów kościelnych. Por. SWP 545; S. Stewart-Sykes, Didascalia degli Apostoli, NDPAC I 1402-1403.

${ }^{34}$ Didascalia Apostolorum XXII, CSCO 407, 220, tłum. własne.

${ }^{35}$ Zob. np. Rdz 18, 19; Wj 12, 26; 13, 14; Pwt 4, 32, 6, 7. 20; Prz 1, 8 . 
Ponieważ wychowanie dzieci ściśle wiąże się z ich zbawieniem, nie jest zaskakujące, że autor Didaskaliów podkreśla, że obowiązkiem rodziców jest wpajanie dzieciom obowiązku posłuszeństwa względem nich. Dzieci muszą poddać się woli rodziców i wskazaniom, które otrzymują od nich na temat prowadzenia cnotliwego życia. Rodzice osiągną sukces $\mathrm{w}$ realizacji tego zadania tylko wtedy, gdy będą upominać swe dzieci i uczyć je słów Pana. Autor Didaskaliów zachęca też rodziców, aby ucząc dyscypliny stosowali wobec swych dzieci kary cielesne. Na poparcie swego stanowiska przytacza on teksty z Księgi Przysłów, aby w ten sposób wykazać, że Biblia wyraźnie wskazuje, że jest to najlepszy sposób, by dobrze wychować dziecko:

„«Gań swego syna, a może będzie nadzieja dla niego» (Prz 19, 18a); «zaprawdę, będziesz bił go rózgą, a zachowasz jego duszę od Szeolu» (Prz 23, 14). I jeszcze mówi: «Ktokolwiek szczędzi rózgi, nienawidzi swego syna» (Prz 13, 24a)"36.

Przytoczenie powyższych tekstów uzasadnia dyscyplinujące użycie kary cielesnej na zasadzie, że wyraża ona miłość rodziców do dzieci.

Jednym z centralnych elementów rad zawartych w Didaskaliach jest wskazanie, aby rodzice nie stwarzali swym dzieciom okazji do przebywania bez nadzoru razem ze swoimi rówieśnikami. W przeciwnym razie dzieci chrześcijańskich rodziców spędzające czas w towarzystwie dzieci pogan, narażone by były na zły wpływ moralny z ich strony ${ }^{37}$. W tym kontekście autor podkreśla, że rodzice powinni wyszukiwać swym dzieciom właściwe zajęcia. Akcent jednak nie jest położony na pracy samej w sobie, lecz na pracy jako jednym z elementów chrześcijańskiego stylu życia, gdyż autor Didaskaliów postrzega pracę jako cnotę, a bezczynność jako wadę. W zaleceniu pracy chodzi o wpojenie dzieciom przekonania, że chrześcijanie sami chcą ciężko pracować, ponieważ obowiązek pracy wynika z nakazu samego Boga (por. np. Rdz 1, 28; 2, 15) oraz nie pozostawia im czasu na społeczny kontakt z poganami. Dzięki wielu zajęciom możliwość takiego kontaktu będzie zredukowana do minimum ${ }^{38}$. Autor obawia się, że jeśli rodzice nie zorganizują dzieciom odpowiedniego zajęcia, to one poprzez bezczynność zaszkodzą sobie ${ }^{39}$.

Didaskalia nie mówią wyraźnie o wychowaniu młodszych dzieci, jednak ciągłe wskazywanie na wielką odpowiedzialność, która spoczywa na rodzi-

${ }^{36}$ Didascalia Apostolorum XXII, CSCO 407, 219, tłum. własne.

${ }^{37}$ Kontekst wydaje się ostrzegać przed kontaktami z młodymi poganami. Na początku rozdziału o wychowaniu dzieci, autor Didaskaliów mówi, że jeśli dzieci nie są „karcone przez rodziców, będą czyniły rzeczy złe, jak poganie" (Didascalia Apostolorum XXII, CSCO 407, 219, tłum. własne).

${ }^{38}$ Rytm chrześcijańskiego życia powinien być wyznaczany dwoma faktorami: pracą i modlitwą w kościele. W rozdziale XIII, autor Didaskaliów podkreśla jak ważne dla chrześcijanina jest regularne chodzenie do kościoła. W tym kontekście poucza, że czas, który chrześcijanin spędza poza kościołem powinien być przeznaczony na pracę, gdyż uczeń Chrystusa powinien zajmować się albo sprawami Bożymi, albo pracą.

${ }^{39}$ Por. Didascalia Apostolorum XXII. 
cach, aby wychowali swych synów na cnotliwych chrześcijan, pozwala na postawienie tezy, że wychowanie chrześcijańskie zaczynało się już we wczesnym dzieciństwie. Podobnie nic nie sugeruje, by wskazania udzielane rodzicom, aby wobec swych młodocianych synów stosowali ostrą dyscyplinę, nie odnosiły się również do młodszych dzieci.

W tym miejscu należy postawić pytanie: kto jest odpowiedzialny za realizację praktycznych aspektów tego wychowania? Pierwszą kwestią, którą należy zauważyć jest fakt, że rodzice są jedynymi osobami wspominanymi w Didaskaliach w tym kontekście. To oni są odpowiedzialni za chrześcijańskie wychowanie; zadanie to nie jest przydzielone niańkom, piastunkom, opiekunkom, pedagogom czy innym służącym. Po drugie, autor Didaskaliów zaznacza, że tę odpowiedzialność powinni ponosić obydwoje rodzice: zarówno ojciec jak i matka. Swe stanowisko autor wyraża przez bezpośrednie zwracanie się do nich w liczbie mnogiej:

„nie dawajcie im zbytniej władzy, aby [nie stanęli] ponad wami - ich rodzicami, i nie pozwalajcie im czynić niczego bez waszej rady" ${ }^{40}$.

Pisze też, że dzieci muszą być „karcone przez swoich rodziców”41 oraz, że rodzice będą musieli zdać sprawę przed Bogiem z grzechów popełnionych przez swe dzieci ${ }^{42}$. Oczywiście wskazanie na fakt, że to obydwoje rodzice są odpowiedzialni za wychowanie dzieci, nie upoważnia do wyciągnięcia wniosku, że autor wyraża $w$ ten sposób przekonanie, że oboje rodzice $w$ równej mierze powinni być zaangażowani w wychowanie swych dzieci. Ustalone wzorce ról matki i ojca przydzielały główną odpowiedzialność ojcu jako paterfamilias, ale w codziennym życiu powierzały też matce wiele praktycznych aspektów wychowania. W Didaskaliach nic nie sugeruje odejścia od norm, ogólnie przyjętych w tej sferze.

2. Konstytucje Apostolskie. W księdze IV tegoż dzieła ${ }^{43}$, znajduje się wypowiedź, która odnosi się do wychowania dzieci. Jest ona w znacznym stopniu oparta na analizowanych powyżej Didaskaliach. Ojcowie są zachęcani w następujący sposób:

„Wy zaś, ojcowie, wychowujcie ( $\pi \alpha \imath \delta \varepsilon v ́ \varepsilon \tau \varepsilon)$ wasze dzieci w Panu, kształ-

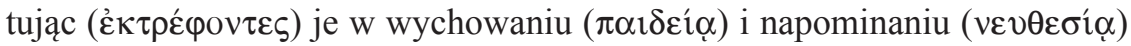

Pana (por. Ef 6, 4); uczcie ich odpowiednich zawodów stosownych do [nauki]

${ }^{40}$ Didascalia Apostolorum XXII, CSCO 407, 219, tłum. własne.

${ }^{41}$ Didascalia Apostolorum XXII, CSCO 407, 219,tłum. własne.

${ }^{42}$ Por. Didascalia Apostolorum XXII.

${ }^{43} \mathrm{~W}$ literaturze przedmiotu najczęściej wskazuje się, że Konstytucje Apostolskie są dziełem prawno-liturgicznym, opracowanym przez anonimowego autora w Syrii (najprawdopodobniej w Antiochii) pod koniec IV w. (najprawdopodobniej w latach 80.). Por. M. Metzger, Introduction, w: SCh 320, Paris 1985, 57-60; M. Szram, Konstytucje Apostolskie, EK IX 733; P. Nautin, Costituzioni Apostoliche, NDPAC I 1250-1251; A. Baron - H. Pietras, Wprowadzenie, w: ŹMT 42, XIII. 
Słowa, aby nie popadły w pychę wskutek dobrobytu i braku rodzicielskiej dyscypliny, żeby nie usamodzielniły się przed czasem i nie sprzeciwiały się temu, co dobre" ${ }^{" 44}$.

Jeśli „wychowanie w Panu” nie będzie realizowane przez ojców, to istnieje niebezpieczeństwo, iż dzieci stopniowo będą podejmować działania przeciwne temu, co jest dobre.

W przeciwieństwie do Didaskaliów, kompilator Konstytucji Apostolskich twierdzi, że kształtowanie dzieci zaczyna się w młodszym wieku, jednak zgadza się z Didaskaliami w kwestii obarczania rodziców odpowiedzialnością za wieczny los ich dzieci i potwierdza, że będą oni ukarani za grzechy swoich dzieci. Chociaż podejście Konstytucji Apostolskich jest nieco łagodniejsze w tej kwestii od stanowiska Didaskaliów, to jednak Konstytucje również wskazują na fakt, że rodzice, którzy zaniedbali wychowanie swych dzieci, będą obarczeni odpowiedzialnością, gdy ich dzieci popadną w grzech rozpusty:

„Jeśli popadną w taki stan [tj. grzech rozpusty] z powodu beztroski (’’ $\mu \dot{\varepsilon} \lambda \varepsilon \imath \alpha v)$ rodziców, rodzice będą odpowiedzialni za ich dusze. Jeśli bowiem przy obojętności ( $\rho \alpha \theta \theta \mu$ í $\alpha$ ) rodziców popadną w rozwiązłe towarzystwo, to dzieci, które popełniły grzech, nie poniosą kary same, lecz potępieni z ich powodu

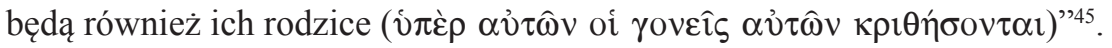

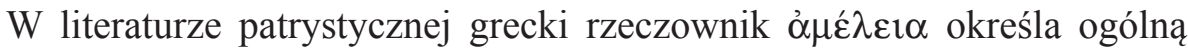
„niedbałość, obojętność”, ale także wyraża - jak w przytoczonym wyżej fragmencie - „moralną obojętność, beztroskę, brak ostrożności”46. Autor piętnuje tych rodziców, którzy zaniedbali podjęcie z należytą powagą zadania wychowania swych dzieci i zapewnienia im należytej formacji, która umożliwiłaby życie zgodne z moralnością chrześcijańską. Ta kategoria rodziców, w ujęciu autora Konstytucji, będzie ukarana przez Boga, gdyż ich codzienna postawa połączona $\mathrm{z}$ brakiem zainteresowania dla moralnego wymiaru wychowania dzieci, doprowadziła je do popełnienia grzechu rozwiązłości. Chociaż autor nie mówi tego bezpośrednio, to należy domniemywać, że groźba kary odnosi się nawet do rodziców, którzy skądinąd prowadzą pobożne życie, nacechowane bojaźnią Bożą. Dlatego, chociaż Konstytucje Apostolskie prezentują nieco łagodniejsze stanowisko niż Didaskalia, to jednak bardzo jasno podkreślają one obowiązek rodziców polegający na konieczności wychowania dzieci w zgodzie z zasadami nauki chrześcijańskiej. Brak gorliwości w tej dziedzinie może mieć dramatyczne konsekwencje w postaci kary Bożej.

Po przytoczeniu tych samych fragmentów zaczerpniętych z Księgi Przysłów, które Didaskalia zaproponowały jako zawarty w Biblii dowód, iż surowa dyscyplina jest najlepszą formą wychowania dzieci, Konstytucje Apostolskie dodają dla podkreślenia tej kwestii jeszcze jeden cytat:

\footnotetext{
${ }^{44}$ Constitutiones Apostolorum IV 11, 1, ŹMT 42, 103.

${ }^{45}$ Tamże IV 11, 5, ŹMT 42, 104.

${ }^{46}$ Por. Lampe, s. 85; Abramowiczówna I 106: „obojętność, niedbalstwo”.
} 
„Okładaj rózgami boki jego, gdy jest jeszcze młody, aby, gdy zmężnieje, nie odmówił ci posłuchu" (Syr 30, 12).

Po zachęceniu rodziców, by uczyli swe dzieci „Słowa Pańskiego”, autor przekonuje ich:

„bądźcie surowi dla nich [tj. dzieci] nawet chłoszcząc je rózgami, wpajajcie im

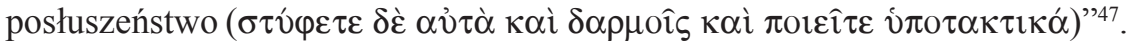

Rodzice zatem są przekonywani przez kompilatora Konstytucji Apostolskich, by używali siły fizycznej w dyscyplinowaniu swoich dzieci, aby uczyły się ulegania ich woli i prowadzenia cnotliwego życia. Podobnie jak autor Didaskaliów, kompilator Konstytucji wychodzi też poza ogólne ostrzeżenia i oferuje teologiczne argumenty w uzasadnieniu takiej postawy.

Zarówno Didaskalia jak i Konstytucje Apostolskie mówią, że rodzice muszą uczyć swe dzieci „Słów Boga”. Didaskalia przez wskazanie to prawdopodobnie mają na uwadze zaznajamianie dzieci z treścią Pisma Świętego, przez co mogą się one uczyć „Słowa Bożego”. Kwestia ta jest o wiele mocniej podkreślona w Konstytucjach Apostolskich. Wskazówki zawarte w Słowie Boga, przekazywane przez rodziców lub odczytywane przez dzieci, są postrzegane jako środek formacji, gdyż dzieci powinny uczyć się okazywania posłuszeństwa swym rodzicom. W tym kontekście podstawowym założeniem jest to, że dzieci powinny podążać za wskazówkami swych rodziców, gdyż rady te dotyczą sensu życia w zgodności z Pismem Świętym.

Należy też zauważyć, że Konstytucje Apostolskie wydają się zakładać, że ojcowie ponoszą podstawową odpowiedzialność za wychowanie. Rozdział poświęcony temu tematowi rozpoczyna się bezpośrednim zwrotem skierowanym do ojców, by przekonać ich, aby kształtowali i wychowywali swoje dzieci w odpowiedni sposób ${ }^{48}$. Również Konstytucje Apostolskie, po-

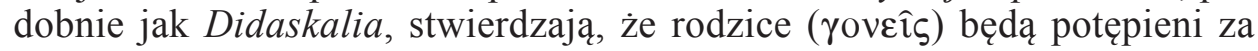
grzechy, które popełnią ich dzieci. W kontekście wypowiedzi, rzeczownik

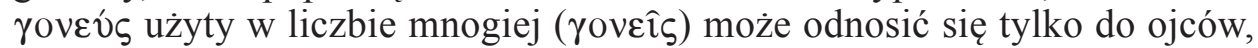
jako jednej grupy rodziców, albo - co jest bardziej prawdopodobne - może też odnosić się do obojga rodziców dziecka ${ }^{49}$. Jeśli taka interpretacja jest właściwa, to oznaczałoby, że również matki są uważane za osoby odpowiedzialne za grzechy swych dzieci. Skoro zaś ponoszą odpowiedzialność za grzechy swych dzieci, to również (wraz z mężami) dzielą odpowiedzialność za wychowanie, które otrzymują dzieci. Chociaż odpowiedzialność ojców jest podstawowa, to jednak wydaje się, że autor w realizacji procesu wychowania uwzględnia też rolę matek.

${ }^{47}$ Constitutiones Apostolorum IV 11, 4, ŹMT 42, 103*.

${ }^{48}$ Por. tamże IV 11, 5; ŹMT 42, 103: „Wy zaś, ojcowie, wychowujcie wasze dzieci w Panu, kształtując je w wychowaniu i napominaniu Pana (por. Ef 6, 4)".

${ }^{49}$ Por. Lampe, s. 321; Liddell - Scott, s. 356; Abramowiczówna I 476. 
3. Jan Chryzostom. Jan Chryzostom był jednym z pierwszych rzeczników wprowadzania w życie rodzinne radykalnych ideałów ascetycznych ${ }^{50}$. Pomimo tego, że cały czas je promował, to jednak jego poglądy na temat małżeństwa i życia rodzinnego ulegały modyfikacji, co widoczne jest zwłaszcza w późniejszych jego pismach, powstałych po opuszczeniu Antiochii. Wydaje się, że złagodzenie stanowiska w tym względzie odzwierciedla jego doświadczenie związane z kontaktami z arystokratycznymi rodzinami Konstantynopola. Antiocheńczyk zdał sobie sprawę $\mathrm{z}$ tego, że jeśli chrześcijaństwo ma przekształcić społeczeństwo, to potrzebuje ono nie tylko duchowej elity, która praktykowałaby radykalne ideały ascetyczne, lecz także rzesz wiernych, którzy na miarę swoich możliwości, na co dzień żyliby Ewangelią. Chryzostom przyznawał, że w dziejach Kościoła jedynie niewielka mniejszość chrześcijan była zdolna do tego, aby wziąć na ramiona ciężar radykalnych ideałów ascetycznych. Dostrzegał też, że jeśli całe społeczeństwo ma być chrystianizowane, to ważne było, aby zdecydowana większość ludzi żyjących swymi zwykłymi sprawami, otrzymała formację zgodną z wiarą chrześcijańską ${ }^{51}$. Antiocheńczyk doskonale zdawał sobie sprawę z tego, że jeśli jego program chrystianizacji ma odnieść sukces, to musi rozpocząć pracę od podstawowej jednostki społecznej - od rodziny i od wychowania dzieci. Jego troska o odpowiedzialność rodziców, aby dali swym dzieciom właściwe wychowanie oraz wskazania dotyczące praktycznej strony tego procesu, znajduje swe odzwierciedlenie w kilku pismach. Jak już zaznaczono, poświęca on temu tematowi całe pismo zatytułowane De inani gloria et de educandis liberis. Problematyka ta obecna jest także w 21. homilii na List do Efezjan (analizującej tekst Ef 6, 1-4) $)^{52}$ oraz w traktacie Adversus oppugnatores vitae monasticae ${ }^{53}$, który został napisany w czasie, kiedy Jan Chryzostom promował radykalne ideały ascetyczne.

Chryzostom przekonuje rodziców, aby wychowanie dzieci w dyscyplinie i Bożych naukach wysunęli na pierwsze miejsce, zaś wszystkie sprawy wychowawcze odnoszące się do doczesności umieścili na drugim miejscu ${ }^{54}$. Łączy także zachęty z krytyką rodziców, którzy są zbyt skoncentrowani na własnych sprawach i bardziej troszczą się o doczesną karierę i sukcesy swych dzieci, niż o ich wieczne zbawienie. W tym względzie Chryzostom dostrzega wielkie zagrożenie, dlatego wysuwa dość radykalną i kontrowersyjną tezę, że większym grzechem jest zaniedbanie chrześcijańskiego wychowania dziecka, niż zabicie go:

\footnotetext{
${ }^{50}$ Po doświadczeniu życia pustelniczego w podantiocheńskich górach, Chryzostom przyjął świecenia kapłańskie (386) i służył Kościołowi antiocheńskiemu jako prezbiter, aż do roku 397, gdy z woli cesarza Arkadiusza został mianowany biskupem Konstantynopola.

${ }^{51}$ Por. Joannes Chrysostomus, De inani gloria et de educandis liberis 19.

${ }^{52}$ Wydanie znajduje się w: PG 62, 149-156.

${ }^{53}$ Wydanie znajduje się w: PG 47, 319-386.

${ }^{54}$ Por. Joannes Chrysostomus, In epistulam ad Ephesios hom. $21,2$.
} 
„Zaostrzyć miecz, uzbroić [nim] swą rękę, zanurzyć w gardle dziecka, nie jest rzeczą tak okrutną, jak zatracić i zniszczyć jego duszę, gdyż niczego nie możemy porównać do duszy" ${ }^{55}$.

Nauczanie Chryzostoma w kwestii czynienia rodziców odpowiedzialnymi za grzechy dzieci jest zgodne z nauką zawartą w Didaskaliach i Konstytucjach Apostolskich. Zbawienie rodziców zależy od ich sukcesu w wychowaniu dzieci, w zabieganiu o to, by stały się chrześcijanami żyjącymi na co dzień zgodnie z zasadami moralności chrześcijańskiej. Na poparcie swej tezy Chryzostom przytacza biblijny opis tego, co przydarzyło się kapłanowi Helemu (por. 1Sm 2, 27-36), kiedy jego upomnienia kierowane pod adresem źle postępujących synów nie przyniosły efektu (por. $1 \mathrm{Sm} 2,22-25$ ). Podkreśla, że sam Heli został ukarany, chociaż wykonywał służbę kapłańską zgodnie z Bożymi prawa$\mathrm{mi}^{56}$. Dlatego rodzice, którzy zaniedbają zbawienie swych dzieci, otrzymają najsurowszą karę ${ }^{57}$. Pod koniec 21. homilii na List do Efezjan, Chryzostom twierdzi, że człowiek, którego dzieci mają buntowniczy charakter, nie wejdzie do królestwa niebieskiego, i zauważa, że rodzice nie mogą być zbawieni tylko z powodu własnej prawości, lecz do osiągnięcia przez nich szczęścia wiecznego wymagana będzie też cnota tych, za których są odpowiedzialni ${ }^{58}$.

Na poparcie przekonania o ciążącym na rodzicach obowiązku wychowania dzieci, Chryzostom przytacza argumenty o charakterze teologicznym. Po pierwsze, podkreśla, że centralną ideą Pisma Świętego jest miłość bliźniego; ponieważ dziecko jest dla rodziców najbliższym bliźnim, zaniedbanie jego wychowania jest najpoważniejszym grzechem, jaki mogą oni popełnićc ${ }^{59}$. Po drugie, przez uczenie dzieci cnót obecnych w Bogu - aby były dobre, łagodne i miłosierne - rodzice „odkrywają i upiększają” podobieństwo swych dzieci do Boga ${ }^{60}$. Po trzecie, Stary Testament wyraźnie wymaga, by dzieci uczyły się znaczenia poszczególnych świąt religijnych i otrzymywały wskazówki dotyczące Prawa Bożego ${ }^{61}$.

Wychowanie zaczyna się już wówczas, gdy dzieci są małe. Chryzostom często podkreśla, że dzieci w młodym wieku o wiele łatwiej można kształtować, a to, czego nauczą się jako dzieci, będzie im towarzyszyło przez życie ${ }^{62}$.

${ }^{55}$ Tenże, Adversus oppugnatores vitae monasticae 3, 4, PG 47, 356, tłum. własne.

${ }^{56}$ Por. tamże $3,3$.

${ }^{57}$ Por. tamże.

${ }^{58}$ Por. tenże, In epistulam ad Ephesios hom. 21, 4.

${ }^{59}$ Por. tenże, Adversus oppugnatores vitae monasticae $3,2$.

${ }^{60}$ Por. tenże, In epistulam ad Ephesios hom. 21, 2. 4. Idea ta jest podstawą metafory stosowanej przez Chryzostoma, w której mówi o dziecku jako o posągu - dziele sztuki, które - dla ukazania pełni jego piękna - musi być obrabiane, polerowane i kształtowane, por. tenże, De inani gloria et de educandis liberis 22; tenże, In epistulam ad Ephesios hom. 21, 1. 4.

${ }^{61}$ Por. tenże, Adversus oppugnatores vitae monasticae 3, 4.

${ }^{62}$ Por. tenże, De inani gloria et de educandis liberis 20 i 25. W rozdziale 37. De inani gloria et de educandis liberis Chryzostom porównuje dzieci do delikatnych kwiatów. Podobnie jak kwiaty „potrzebują wiele opieki, póki są młode”, tak też i dzieci od najmłodszych lat wymagają 
Kiedy dzieci osiągną wiek sześciu lub siedmiu lat, rodzice powinni skoncentrować się na opowiadaniu im historii zaczerpniętych z Biblii ${ }^{63}$. Zamiast opowiadania historyjek, które koncentrują się na rzeczach moralnie $\mathrm{złych}^{64}$, ci, którzy znajdują się w najbliższym otoczeniu dziecka, powinni mówić o rzeczach odnoszących się do Pisma Świętego. Antiocheńczyk ostrzega rodziców, aby nie zadawali pytania: czy słuchanie odczytywanych tekstów Pisma Świętego jest dla dzieci konieczne?, gdyż każdy musi wiedzieć o czym mówi Pismo Święte, a jest to szczególnie ważne dla dzieci. Dlatego od najwcześniejszych lat powinny one zaznajamiać się z Pismem Świętym ${ }^{65}$. Chryzostom występuje też przeciw obiegowemu przekonaniu, że tylko mnisi powinni studiować Pismo Święte. W tym kontekście uzasadnia, że zwyczajni, przeciętni chrześcijanie, którzy na co dzień muszą żyć w burzliwym świecie, mają większą potrzebę studiowania Pisma Świętego niż ci, którzy prowadzą życie pustelnicze ${ }^{66}$. Zatem rodzice powinni przypominać swoim dzieciom opowiadania z Pisma Świętego ${ }^{67}$. Antiocheńczyk zachęca też rodziców, aby swym dzieciom śpiewali duchowe pieśni i od najmłodszych lat zabierali je ze sobą do kościoła ${ }^{68}$.

Podobnie jak Didaskalia i Konstytucje Apostolskie, Chryzostom ostrzega rodziców, aby chronili swe dzieci przed złym wpływem otaczającego ich świata pogańskiego, szczególnie wtedy, kiedy osiągną dojrzałość płciową ${ }^{69}$. Rodzice nigdy nie powinni pozwalać chłopcom na wyjście do teatru, ponieważ to, co oni tam zobaczą i usłyszą, może ich zdemoralizować ${ }^{70}$. Ponadto Chryzostom podkreśla, że młodzi chłopcy powinni mieć ograniczony kontakt z dziewczę-

troski rodziców. Dlatego Antiocheńczyk zachęca rodziców, aby pomyśleli o dobrych opiekunach dla dzieci, ,,aby od początku miały solidny fundament i nie słyszały nic złego”. Jan Chryzostom nie był jedynym autorem starożytnego świata, który miał świadomość, że impulsy na które dzieci są wystawiane podczas gdy są małe, mają wielkie znaczenie dla kształtowania ich osobowości. Był to pogląd szeroko rozpowszechniony w starożytności: por. Plato, Leges VII 789; tenże, Respublica II 377 A-B; Aristoteles, Politica VII 1336a10; Quintilianus, Marcus Fabius, Institutio oratoria I 1, 36; Pseudo-Plutarchus, Moralia 3E-F. Por. T. Morgan, Literate Education in the Hellenistic and Roman Worlds, Cambridge 1998, s. 255-261.

${ }^{63}$ Por. Joannes Chrysostomus, De inani gloria et de educandis liberis 52, SCh 188, 150, BOK 19, 92: „Gdy dziecko podrośnie, opowiedz mu jeszcze inne historie [biblijne]. Napełnią je one zbawienną bojaźnią".

${ }^{64}$ Por. tenże, De inani gloria et de educandis liberis 38.

${ }^{65}$ Por. tenże, In epistulam ad Ephesios hom. 21, 3.

${ }^{66}$ Por. tamże 21, 2, PG 62, 152, tłum. własne: „Człowiek, który nigdy nie podróżuje morzem nie potrzebuje wiedzieć jak wyposażyć statek, gdzie znaleźć sternika lub załogę, ale żeglarz musi znać wszystkie te rzeczy. To samo odnosi się do mnicha i człowieka światowego. Mnich żyje niekłopotliwym życiem w spokojnym porcie z dala od wszelkich nawałnic, natomiast człowiek światowy zawsze żegluje przez ocean walcząc z niezliczonymi nawałnicami”.

${ }^{67}$ Por. tenże, De inani gloria et de educandis liberis 39-46.

${ }^{68}$ Por. tamże 41.

${ }^{69}$ Por. tamże 77.

${ }^{70}$ Por. tamże 78, SCh 188, 180-183, BOK 19, 100: „Mój synu, wolnym nie wypada chodzić do teatru, gdzie występują obnażone kobiety, prowadzą bezwstydne rozmowy. Wiedz, że gdyby w te- 
tami $^{71}$. Przy lekturze dzieła De inani gloria et de educandis liberis można dostrzec, iż w toku udzielania rad związanych z wychowaniem młodzieńców, Chryzostom coraz bardziej ogranicza możliwość ich kontaktu z dziewczętami, by ostatecznie stwierdzić, że młodzieniec nie powinien ,przestawać z żadną kobietą, wyjąwszy jego matkę"72. Złotousty kaznodzieja proponuje też środek zaradczy przeciw pragnieniu zmysłowej rozkoszy, które - jak mówi - „we wnętrzu człowieka żarzy się [jak] ogien [...] wywierający nacisk na naturę"73. Wskazuje, że wychowawcy i służący powinni uczyć młodzieńców pieśni religijnych $^{74}$ i ukierunkowywać ich uwagę na piękno otaczającego ich świata: „na niebo i gwiazdy, na ziemię i jej kwiaty, na łąki i obrazki w kwiatach”75. Rodzice natomiast powinni mówić swym synom o pięknie duszy, upominać ich, aby szlachetnie zachowywali się względem kobiet $^{76}$, oraz zapewniać ich, że - gdy przyjdzie na to czas - znajdą im cnotliwe żony ${ }^{77}$. We wskazaniach tych zawarta jest ogólna idea, że młodzieniec nie powinien interesować się płcią odmienną, aż do czasu wstąpienia na ślubny kobierzec. Chryzostom także ostrzega rodziców, aby młodzieńcom nie dawali pieniędzy ${ }^{78}$. Zalecenie to prawdopodobnie podyktowane było pokusą do odwiedzania osób i miejsc mających zły wpływ na młodzież ${ }^{79}$. Rodzice także powinni uczyć młodzieńców pogardy dla wszelkich form luksusu ${ }^{80}$.

Antiocheńczyk podkreśla jak ważne jest ukazywanie dzieciom dobrych przykładów ludzi wstrzemięźliwych i żyjących w czystości oraz trzymanie się towarzystwa takich osób ${ }^{81}$. W ujęciu Chryzostoma innymi elementami pomagającymi kształtować dziecko do życia w cnocie są: praktykowanie postu, uczęszczanie do kościoła ${ }^{82}$, pobożna i szczera modlitwa oraz czuwanie „W miarę możności”"83.

Podobnie jak kompilatorzy Didaskaliów i Konstytucji Apostolskich, również Chryzostom jest zwolennikiem używania siły fizycznej względem dzieci, gdyż w systemie wychowania, który proponuje, groźby i strach są elementami

atrze nic się nie słyszało i nic się nie widziało nieprzyzwoitego, można by tam pójść. Ale tam słyszy się tylko nieprzyzwoite mowy i to, co tam się dzieje niegodne jest twych oczu".

${ }^{71}$ Por. tamże 60.

${ }^{72}$ Tamże 62, SCh 188, 160, BOK 19, 94.

${ }^{73}$ Tamże 60, SCh 188, 158, BOK 19, 94.

${ }^{74}$ Por. tamże 60.

${ }^{75}$ Tamże 59, SCh 188, 156-158, BOK 19, 94.

${ }^{76}$ Por. tamże 62.

${ }^{77}$ Por. tamże 61.

${ }^{78}$ Por. tamże 62.

${ }^{79}$ Por. O.M. Bakke, Upbringing of Children in the Early Church. The Responsibility of Parents, Goal and Methods, „Studia Theologica. Nordic Journal of Theology” 60 (2006) 155-156.

${ }^{80}$ Por. Joannes Chrysostomus, De inani gloria et de educandis liberis 62.

${ }^{81}$ Por. tamże 78-79.

${ }^{82}$ Por. tamże 79, SCh 188, 182-184, BOK 19, 100: „Niech chłopiec przyzwyczai się do postu przynajmniej dwa dni w tygodniu - w środę i w piątek. Niech też uczęszcza do kościoła”.

${ }^{83}$ Tamże 80, SCh 188, 186, BOK 19, 101. 
fundamentalnymi. Niemniej jednak w De inani gloria et de educandis liberis proponuje on nieco łagodniejsze podejście do dzieci niż proponowali to kompilatorzy analizowanych wyżej tekstów. Choć wydaje się, że Chryzostom w późniejszym czasie zaostrzył swoje poglądy na temat surowości rodziców, którą powinni okazywać wobec swych dzieci. W Adversus oppugnatores vitae monasticae mówi o grzesznym postępowaniu synów Helego (por. 1Sm 2, 12-17) i jego konsekwencjach dla samego kapłana i wyjaśnia, że Heli zbyt słabo dyscyplinował swych synów. Antiocheńczyk krytykuje tę słabość Helego i podkreśla, że powinien grozić im, mieć w zasięgu wzroku, używać rózgi i być bardziej srogim ${ }^{84}$. Jest prawdą, że wypowiedź ta wyraźnie nie przekonywała rodziców, by używali siły fizycznej jako narzędzia wychowania, jednak sam fakt, że postępowanie Helego obrazuje negatywny przykład, daje do zrozumienia, że powinni używać siły fizycznej do właściwego i skutecznego wychowania dzieci. To przekonanie jest uzasadnione stwierdzeniem Chryzostoma, że Heli został ukarany przez Boga za niezdyscyplinowanie swych synów z wystarczającą surowością.

Chociaż nagany i groźby zastosowania kary fizycznej odgrywają istotną rolę w programie wychowawczym Chryzostoma, to jednak ma on świadomość, że traktowanie dziecka z łagodnością oraz kierowanie pod jego adresem różnych obietnic, również może być skutecznym sposobem kształtowania $\mathrm{go}^{85}$. W omawianych pismach Antiocheńczyk tylko wspomina o pozytywnym efekcie obietnicy nagrody dla dziecka, jednak nie przytacza przykładów nagród jakie stosowano. Natomiast w jednej z homilii na List do Kolosan twierdzi, że każdy wie, iż rodzice kupują dzieciom łakocie i dają im pieniądze jako nagrodę za chodzenie do szkoły ${ }^{86}$. Chryzostom także radzi rodzicom, aby odwoływali się do satysfakcji dziecka jakiej doświadcza, kiedy jest chwalone przez innych ludzi i kiedy dostrzega, że czegoś nauczyło się. Jako przykład podaje radość dziecka, którą odczuwa ono podczas pobytu w kościele, gdy usłyszy historię z Pisma Świętego, którą dobrze zna, podczas gdy żadne z innych dzieci nie jest $\mathrm{z}$ nią obeznane ${ }^{87}$. Antiocheńczyk utrzymuje, że potrzeba pozytywnej afirmacji i uznania przez innych, jest fundamentalną cechą natury ludzkiej i elementem dowartościowującym ludzką osobę ${ }^{88}$. Pozytywna reakcja ludzi znajdujących się w otoczeniu dzieci motywuje je do dobrego działania. Gdy widzą one, że ich zachowanie jest chwalone, będą wytężać swe wysiłki w tym zakresie ${ }^{89}$.

${ }^{84}$ Por. tenże, Adversus oppugnatores vitae monasticae 3, 3.

${ }^{85}$ Por. tenże, De inani gloria et de educandis liberis 30 . O poglądach Chryzostoma na temat użycia kary i nagród w wychowaniu zob. J. Seidlmayer, Die Pädagogik des Johannes Chrysostomus, Münster 1926, 45-58; A. Danassis, Johannes Chrysostomos: Pädagogisch-Psychologische Ideen in seinem Werk, Bonn 1971, 178-190.

${ }^{86}$ Por. Joannes Chrysostomus, In epistulam ad Colossenses hom. 4, 3.

${ }^{87}$ Por., tenże, De inani gloria et de educandis liberis 41.

${ }^{88}$ Por. Danassis, Johannes Chrysostomos, s. 188-190.

${ }^{89}$ B. Leyerle, Appealing to Children, JECS 5 (1997) 257 twierdzi, że w porównaniu z naganą 
Chryzostom thumaczy, że rodzice w procesie wychowania swych dzieci powinni stosować zarówno kary, jak i nagrody. To dwuwymiarowe podejście do kwestii wychowania jest wzorowane na stosunku Boga do świata:

„Tak i Bóg wychowuje ludzi - groźbą kary piekła i obietnicą nagrody nieba.

Podobnie i my winniśmy się odnosić do dzieci" ${ }^{\prime 90}$.

Argument ten daje teologiczne uzasadnienie zarówno dla stosowania kary, jak i dawania nagród.

Na zakończenie pozostaje przedstawienie kwestii: kto jest odpowiedzialny za wychowanie dzieci? Na początku rozważań zauważono, że w klasycznej rodzinie ojciec jako paterfamilias ponosił całkowitą odpowiedzialność za wychowanie dzieci. Chryzostom podejmuje tę myśl i w jednej z homilii na List do Efezjan, wyraźnie twierdzi, że ojciec, jako głowa i źródło władzy w rodzinie ${ }^{91}$, jest odpowiedzialny za uczenie swoich dzieci posłuszeństwa. Jednak matki nie są odsunięte od wychowania dzieci. Chryzostom zwraca się do nich bezpośrednio i zachęca do refleksji nad godnym pochwały przykładem Anny, która powierzyła Bogu swoje dziecko - Samuela ${ }^{92}$. Bardziej interesujący jest fakt, że włącza on matki w całość odpowiedzialności za wychowanie, kiedy przedstawia metaforę dziecka jako posągu w ręku artysty ${ }^{93}$. Antiocheńczyk zwraca się do rodziców: „ojcowie i matki”94, a następnie przekonuje ich: „musicie wkładać wszystek trud, aby swe dzieci wychować na piękne obrazy Boga" ${ }^{95}$. Wypowiedzi te jednoznacznie wskazują, że również matki ponoszą odpowiedzialność za wychowanie i wraz z ojcami dzielą trud praktycznej realizacji tego zadania. Kiedy ojciec opowiada historię zaczerpniętą z Pisma Świętego, matka powinna być przy tym obecna, aby mogła „chwalić opowiadanie”. Po tym jak ojciec przedstawił po raz pierwszy opowieść, zadaniem matki jest powtórzyć ją i sprawdzić, czy chłopiec już ją zapamiętał ${ }^{96}$. Zbyt odważne jest twierdzenie, że Chryzostom widzi to jako standardowy wzór wychowania $\mathrm{w}$ domu, jednak z pewnością przydziela on matkom ważną rolę w instruowa-

\footnotetext{
i groźbami kary cielesnej, w systemie wychowawczym Chryzostoma jest preferowany „program bodźca" (a program of inducement), jednak wydaje się, że analizowane i przytoczone teksty nie uzasadniają takiej interpretacji. Teksty źródłowe wyraźnie wskazują, że kara (lub groźba kary) jest najważniejszym elementem wychowawczym występującym w pismach Jana Chryzostoma i temu zagadnieniu poświęca on najwięcej miejsca i uwagi. Podobnego zdania jest O.M. Bakke (Upbringing of Chldren, s. 163, nota 66).

${ }^{90}$ Joannes Chrysostomus, De inani gloria et de educandis liberis 67, SCh 188, 166, BOK 19, 96.

${ }^{91}$ Por. tenże, In epistulam ad Ephesios hom. 21, 1.

${ }^{92}$ Por. tamże 21, 2.

${ }^{93}$ Por. tenże, De inani gloria et de educandis liberis 22.

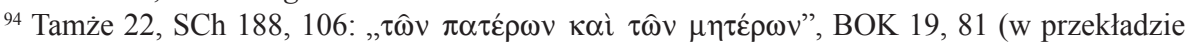
polskim użyta jest liczba pojedyncza, jednak oryginalny tekst grecki zawiera formy liczby mnogiej; z tego względu dokonano korekty tekstu).

${ }^{95}$ Tamże 22, SCh 188, 108, BOK 19, 81.

${ }^{96}$ Por. tamże 39-40.
} 
niu swych dzieci w poznawaniu treści Pisma Świętego. Antiocheńczyk zaleca też, aby mężowie zachęcali swe żony do rozmów z dziećmi, i do udzielania im rad związanych z życiem codziennym ${ }^{97}$. Rola matki w wychowaniu dzieci jest najlepiej określona we wskazaniu jej jako drugiej w kierowaniu domem i działającej w imieniu męża ${ }^{98}$.

Zaprezentowane powyżej teksty źródłowe, chociaż nie były liczne, pozwalają na sformułowanie kilku wniosków natury ogólnej. Przede wszystkim należy zauważyć, że teksty te zawierają gorące zachęty, aby wychowywać dzieci w zgodzie z ideałami chrześcijańskimi. Rodzice są uwrażliwiani, aby potrafili dostrzec potrzebę wszechstronnego kształcenia moralnego i wychowania religijnego swych dzieci oraz chronienia ich przed negatywnymi wpływami otaczającego je świata. Chociaż w starożytności przedchrześcijańskiej kształtowanie moralne było ostatecznym celem wychowania (przynajmniej w kilku szkołach filozoficznych), to jednak wydaje się, że chrześcijańskie teksty mocniej podkreślają, iż rodzice mają obowiązek uczenia swych dzieci życia w cnocie. W tej materii zauważa się uderzającą różnicę pomiędzy stanowiskiem Cycerona, który twierdził, że ojcowie nie mogą być obwiniani za błędy swych synów, a stanowiskiem reprezentowanym przez źródła chrześcijańskie, w których odpowiedzialność za wychowanie dzieci wpisuje się nawet w kwestię wiecznego zbawienia. Chrześcijańskie wychowanie dzieci ma tak fundamentalne znaczenie, że zbawienie rodziców uzależnione jest od poważnego podjęcia tego zadania i od powodzenia w wychowaniu dzieci w zgodzie z ideałami chrześcijańskimi.

Chrześcijańskie teksty wydają się przemawiać za bardziej wydatnym użyciem kary cielesnej przez ojca rodziny niż wskazywałby na to klasyczny ideał bonus paterfamilias. Tę kwestię można wyjaśnić odwołując się do tekstów biblijnych, przywoływanych przez źródła chrześcijańskie, które nie tylko zachęcają, lecz wręcz nakazują używanie siły fizycznej („rózgi”). Cytowane teksty z Księgi Przysłów i Księgi Syracha, uzasadniały stosowanie kary cielesnej prawdziwą miłością do dziecka. Również historia Helego i jego synów

\footnotetext{
${ }^{97}$ Por. tamże 32.

${ }^{98}$ Stanowisko to koresponduje z Chryzostomowym opisem relacji między małżonkami i ich dziećmi, opartym o tekst 1 Listu do Tymoteusza $(3,4)$. Fragment ten mówi o tym, że ten, kto ma być biskupem, musi dobrze rządzić własnym domem i utrzymywać dzieci w uległości, która polega na posłuszeństwie dzieci i okazywaniu przez nie szacunku wobec ojca. To prowadzi Chryzostoma do nakreślenia analogii między Kościołem a gospodarstwem domowym: „Albowiem Kościół jest jakoby wielki dom. I jak w domu są synowie, żona, słudzy, a mąż ma władzę nad wszystkimi, tak i w Kościele nie ma nic innego, jak to samo: synowie, niewiasty, słudzy. A jeśli przełożony Kościoła ma wspólników rządu, to także w domu mąż ma za wspólniczkę żonę" (Joannes Chrysostomus, In epistulam I ad Timotheum hom. 10, 2, PG 62, 549, thum. T. Sinko, w: Św. Jan Złotousty, Homilie na Listy Pasterskie św. Pawta i na List do Filemona (Tym. I, II. Tyt. Filem.), Kraków 1949, 105.
} 
(por. 1Sm 2, 12-37) stanowiła argument dla konieczności dyscyplinowania dzieci. Jednak najbardziej oczywistym wyjaśnieniem kwestii stosowania kary cielesnej względem dzieci jest fakt, że zaprezentowani autorzy byli głęboko przekonani, że dla chrześcijanina najważniejsze jest zbawienie, a w przypadku źle postępujących dzieci, było one zagrożone. Zatem ostatecznym celem wychowania było zbawienie dziecka (i rodziców), i jest rzeczą oczywistą, że aby osiągnąć ten cel rodzice musieli używać surowych, lecz skutecznych metod, o czym wspominani autorzy byli głęboko przekonani. Oznaczałoby to, że chrześcijanie nie byli zwolennikami stosowania kar cielesnych względem dzieci z powodu nakazów w tym względzie, zawartych w Piśmie Świętym, lecz z powodu przekonania, że są one najskuteczniejszym środkiem wychowania, a tekstów biblijnych używali tylko po to, aby uzasadnić swe własne poglądy i postawy.

Ponadto teksty chrześcijańskie wyraźnie wskazują rodziców jako wychowawców i nauczycieli dzieci oraz osoby odpowiedzialne za ich formację chrześcijańską. To zakłada ukształtowanie pewnego nowego ideału, odmiennego od zaproponowanego przez starożytnych autorów pogańskich (przynajmniej w bogatych rodzinach), w myśl którego rodzice powinni być bezpośrednio zaangażowani w wychowanie. W chrześcijańskich źródłach nianie, piastunki, pedagodzy i nauczyciele nie odgrywają kluczowej roli w wychowaniu dzieci.

Z wyżej zaprezentowanych treści jasno wynika, że starożytni myśliciele chrześcijańscy obficie czerpali z dorobku kultury klasycznej w dziedzinie wychowania dzieci i starali się przeszczepiać wartościowe ideały na grunt chrześcijański, nadając im jednak inny wymiar i podporządkowując innemu celowi.

\section{RESPONSIBILITY FOR THE UPBRINGING OF CHILDREN IN THE CHOSEN EARLY CHRISTIAN LITERATURE}

\section{(Summary)}

This article is a presentation of the problem of parents' responsibility in raising their children. The first part shows a few general, but fundamental aspects of child upbringing in the Greco-Roman world. The next part describes ancient Christian texts written in Syria about the given problem (Didascalia Apostolorum, Constitutiones Apostolorum and selected works by St. John Chrysostom). These texts contain sincere admonishments to bring up children in accord with Christian ideals. Parents were sensitized to see the need for well-rounded moral and religious education of their children as well as for guarding them from negative influence of the surrounding world. The ultimate goal of such education was the salvation of the child (and the parents). In order to achieve this aim parents were required to use severe methods such as physical punishment, and to become more involved as educators, teachers and people responsible for the Christian formation of their children. It appears from these texts that although ancient Christian thin- 
kers drew extensively from the achievements of classical culture in the field of child education and tried to transplant worthy ideals on the Christian ground, yet they gave them a different dimension and directed them toward a different aim.

Słowa kluczowe: wychowanie dzieci, odpowiedzialność rodziców, Didascalia Apostolorum, Constitutiones Apostololum, Jan Chryzostom.

Key words: child upbringing, parent responsibility, Didascalia Apostolorum, Constitutiones Apostolorum, John Chrysostom. 